\title{
Changes in the Depth Profile of Surface Films on Alloy 600 in High Temperature Water*
}

\author{
Takeshi Sakai**, Kazuhiko Aoki**, Toshinori Shigemitsu** and Yasutada Kishi** \\ ** Engineering Service Div. Nuclear Fuel Industries, Ltd.
}

\begin{abstract}
The aqueor's oxidation of Alloy $600 \mathrm{MA}$ (mill annealed) and TT (thermally treated) materials in acidic, neutral and basic $\mathrm{pHs}(\mathrm{pH} \mathrm{4.5,7,10}$ and 14) under low and high dissolved oxygen concentrations $\left(\mathrm{DO}_{2}<5 \mathrm{ppb}, \simeq 4 \mathrm{ppm}\right)$ has been studied using a once-through (refreshed) autoclave and Auger electron spectroscopy. The in-depth profile of composition of oxide films on Alloy 600 was measured using an argon sputtering method. Both $\mathrm{pH}$ and $\mathrm{DO}_{2}$ have an effect on oxide film composition and also a change in these parameters is reflected by a change in the film depth profile.
\end{abstract} copy

Key words: corrosion, Alloy 600, oxide film, steam generator, auger electron spectros-

\section{Introduction}

Intergranular attack (IGA) is one of the major corrosion damages that occurs on the secondary side surface of Alloy 600 steam generator (SG) tubes in the hot leg tubesheet (TS) and tube support plate (TSP) crevices at several pressurized water reactor (PWR) plants. ${ }^{1)}$ Although much research work has been conducted to identify the cause of IGA in order to select effective countermeasures, ${ }^{2)}$ traditional water chemistry techniques have not been able to identify the specific causative agent of the IGA.

In order to learn more about this corrosion problem, studies on surface oxide films in corrosive solutions were initiated recently. ${ }^{3 \sim 8)}$ In general, when an alloy reacts with an aqueous solution, a thin surface film is formed. Since the surface film is an interface between an alloy and its environment, it was postulated that the characteristics of the film could be affected by the environment. Further, the formation and disruption of the film could be related to the corrosion processes of the alloy in the environment.

Results of studies on surface films may be

* 4th International Symposium on Environmental Degradation of Materials in Nuclear SystemsWater Reactors, Jekyll Islands, GA, USA. (1989).

** 950, Ohaza-Noda, Kumatori-cho, Sennan-gun, Osaka, 590-04 Japan. useful to infer:

(1) the detailed relationship between surface film depth profile and water chemistry conditions such as $\mathrm{pH}$, dissolved oxygen and temperature.

(2) the electrochemical behavior of the alloy in high temperature water, and

(3) the corrosion resistance of the film.

In studies on the films, the Pourbaix dia$\operatorname{gram}^{9), 10)}$ is an useful theoretical tool to evaluate the correlation between the water chemistry condition and the film characteristics. ${ }^{11), 12)}$ However, the Pourbaix diagram displays theoretical thermodynamic stability of a chemical species in the equilibrium condition only, while the growth of a thin film is a dynamic phenomenon of mixed physicochemical reactions, such as diffusion of metal constituents and oxygen, formation of oxide and dissolutionprecipitation of chemical species. Therefore, it is suspected that the actual thin film characteristics can not be completely characterized by the equilibrium data. To make correct interpretations of the thin film characteristics, it was considered necessary to perform parameter surveys experimentally to investigate the effect of the main environmental parameters $(\mathrm{pH}$, dissolved oxygen) on the thin film.

The current study was performed as part of a larger effort to provide methods to improve the corrosion resistance by controlling film formation. A laboratory experiment was per- 
Table 1 Chemical composition (wt \%) and heat treatments of Alloy 600.

\begin{tabular}{|c|c|c|c|c|c|c|c|c|c|c|c|}
\hline & $\begin{array}{c}\text { Heat } \\
\text { Treatment }\end{array}$ & $\mathrm{C}$ & $\mathrm{Si}$ & $\mathrm{Mn}$ & $\mathrm{P}$ & $\mathrm{S}$ & $\mathrm{Cu}$ & $\mathrm{Ni}$ & $\mathrm{Cr}$ & $\mathrm{Fe}$ & $\mathrm{Co}$ \\
\hline $600 \mathrm{MA}$ & $925^{\circ} \mathrm{C} \times 3 \mathrm{~min}$ & 0.03 & 0.29 & 0.30 & 0.008 & 0.001 & 0.01 & 74.55 & 15.85 & 8.4 & 0.02 \\
\hline $600 \mathrm{~T}$ & & 0.03 & 0.30 & 0.32 & 0.007 & 0.001 & 0.01 & 74.05 & 16.10 & 8.6 & 0.02 \\
\hline
\end{tabular}

formed to obtain a data base on surface film depth profile of Alloy 600 in high temperature water to determine the following:

(1) Effect of $\mathrm{pH}$ on surface film.

(2) Effect of dissolved oxygen on surface film.

The autoclave testing and the subsequent thin film analysis by Auger electron spectroscopy have clarified the correlation between surface film depth profile and environmental parameters ( $\mathrm{pH}$ and dissolved oxygen) quantitatively.

\section{Experimental}

\subsection{Experimental procedure}

The specimens were cut from Alloy 600 steam generator tubing of $22.23 \mathrm{~mm}$ O.D. $\times 1.27 \mathrm{~mm}$ in thickness. The chemical compositions and heat treatments of test specimens are shown in Table 1. Two heats of tubing were selected to compare the effect of heat treatment on the surface film of Alloy 600:mill annealed material (600 MA) and thermally treated material (600 TT).

The surface of the specimens was polished by No. 600 grit $\mathrm{SiC}$ paper. After ultrasonically cleaning in acetone, the specimens were set up in the autoclave.

The autoclave system in this study was a refreshed type, so called, once-through method. For the deaeration test, a low level of dissolved oxygen $\left(\mathrm{DO}_{2}\right)$ of less than $5 \mathrm{ppb}$ was attained by high purity nitrogen $\left(\mathrm{N}_{2}\right)$ degassing of the entire system before testing and by the $\mathrm{N}_{2}$ gas deaeration of the feed water.

The flow rate of the test solution during heatup was maximized and it was held at $1.51 / \mathrm{h}$ at test temperature for 1 week and also during cool-down. The inner volume of the autoclave was 51. Thus complete refreshment of the autoclave water was once every $3.3 \mathrm{~h}$.

After exposure in this high temperature environment for 1 week $(168 \mathrm{~h})$, the test specimens were removed from the autoclave, rinsed
Table 2 Test matrix for $\mathrm{pH}$ and dissolved oxygen effect.

\begin{tabular}{|c|c|c|c|c|}
\hline \multirow{2}{*}{ Test No. } & \multicolumn{2}{|c|}{ Test Solution } & \multirow{2}{*}{ Specimen 2} & \multirow{2}{*}{$\begin{array}{c}\text { Test } \\
\text { Condition }\end{array}$} \\
\hline & $\mathrm{pH}^{* 1}$ & $\mathrm{DO}_{2}$ & & \\
\hline $1-1$ & 4.5 & \multirow{4}{*}{$<5 \mathrm{ppb}$} & \multirow{7}{*}{ MA } & \multirow{7}{*}{$\begin{array}{c}280^{\circ} \mathrm{C} \\
\times \\
168 \mathrm{~h} \\
(1 \text { week) }\end{array}$} \\
\hline 1.2 & 7 & & & \\
\hline $1-3$ & 10 & & & \\
\hline 1.4 & 14 & & & \\
\hline $11-1$ & 4.5 & \multirow{3}{*}{$\simeq 4 \mathrm{ppm}$} & & \\
\hline $11-2$ & 7 & & & \\
\hline $11-3$ & 10 & & & \\
\hline
\end{tabular}

*1 $\mathrm{pH}$ at room temperature.

The $\mathrm{pH}$ value is adjusted by $\mathrm{HCl}$ and $\mathrm{NaOH}$ for acidic and basic condition, respectively.

$* 2 \mathrm{MA}=600 \mathrm{MA}, \mathrm{TT}=600 \mathrm{TT}$.

Table 3 Test matrix for the effect of $\mathrm{pH}$ change.

\begin{tabular}{|c|c|c|c|c|}
\hline \multirow{2}{*}{$\begin{array}{l}\text { Test } \\
\text { No. }\end{array}$} & \multicolumn{2}{|c|}{ Solution $\mathrm{pH}^{* 1}$} & \multirow{2}{*}{ Specimen 2} & \multirow{2}{*}{$\begin{array}{c}\text { Test } \\
\text { Condition }\end{array}$} \\
\hline & $\begin{array}{l}\text { 1st } 168 \mathrm{~h} \\
\text { (1week) }\end{array}$ & $\begin{array}{l}\text { 2nd 168h } \\
\text { (1week) }\end{array}$ & & \\
\hline III-1 & 7 & 14 & \multirow{3}{*}{$\begin{array}{c}\text { MA } \\
\pi\end{array}$} & \multirow{3}{*}{$\begin{array}{c}280^{\circ} \mathrm{C} \\
\times \\
168 \mathrm{~h}(1 \mathrm{st}) \\
+ \\
\left.\begin{array}{c}168 \mathrm{~h}(2 \mathrm{nd}) \\
\text { Total } 336 \mathrm{~h} \\
=2 \text { weeks }\end{array}\right)\end{array}$} \\
\hline $111-2$ & 14 & 7 & & \\
\hline III-3 & 14 & 4.5 & & \\
\hline
\end{tabular}

*1 $\mathrm{pH}$ at room temperature. $\mathrm{DO}_{2}<5 \mathrm{ppb}$.

The $\mathrm{pH}$ value is adjusted by $\mathrm{HCl}$ and $\mathrm{NaOH}$ for acidic and basic condition, respectively.

*2 $\mathrm{MA}=600 \mathrm{MA}$, TT $=600 \mathrm{TT}$.

with pure water and kept in a vacuum desiccator for the subsequent analysis on the surface film.

Auger electron spectroscopy (AES, JEOL Model JAMP-30) was used to conduct the quantitative elemental distribution analysis of the depth profile of the surface films. The depth profile was obtained by the argon ion sputtering and AES measurement alternately. The sputtering rate was $285 \AA /$ min for a $\mathrm{SiO}_{2}$ standard sample and the diameter of the analyzed region was about $200 \mu \mathrm{m}$.

\subsection{Test matrix}

The values of the salient test parameters of the present study are summarized in Tables 2 and 3. Table 2 is for the one-week autolcave testing and shows the various steady-state values for $\mathrm{pH}$ and $\mathrm{DO}_{2}$. Table 3 shows the test matrix of the two-week autoclave tests in which $\mathrm{pH}$ was changed after the first week test. In this test, specimens were removed from the autoclave after the first week test and returned 


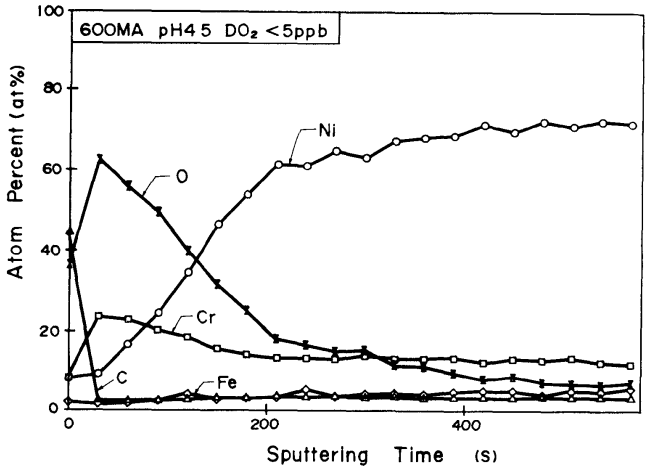

Fig. 1 Depth profile of Alloy $600 \mathrm{MA}$. Test condition: $\mathrm{pH} 4.5, \mathrm{DO}_{2}<5 \mathrm{ppb}$, $280^{\circ} \mathrm{C} \times 168 \mathrm{~h}$.

to the autoclave when the change in solution was established for the second week test.

\section{Results and discussion}

\subsection{Effect of $\mathrm{pH}$ and dissolved oxygen}

Figure 1 shows the typical depth profile of the surface film on Alloy $600 \mathrm{MA}$ for the Test No. I-1 in Table 2.

In order to compare these surface film depth profiles quantitatively, four parameters were used: $\mathrm{Ni}$ at $\%, \mathrm{Cr}$ at $\%, \mathrm{Ni} / \mathrm{Ni}+\mathrm{Cr}+\mathrm{Fe}$ at $\%$ ratio and $\mathrm{Cr} / \mathrm{Ni}+\mathrm{Cr}+\mathrm{Fe}$ at $\%$ ratio. The film region was defined to be the area where $\mathrm{Ni}$ at $\%$ is less than $60 \%$. This definition is somewhat arbitrary; for example, it is better to distinguish the deposit region from the film region when static autoclave tests are conducted in the contaminated solutions. However, the present study, no contaminants were added to the solution and the refreshed type autoclave was used and the above criteria for the film region was selected. ${ }^{13)}$ The typical depth profiles of $\mathrm{Ni} / \mathrm{Ni}+\mathrm{Cr}+\mathrm{Fe}$ at $\%$ ratio and $\mathrm{Cr} / \mathrm{Ni}+$ $\mathrm{Cr}+\mathrm{Fe}$ at $\%$ ratio are shown in Fig. 2 for Alloy $600 \mathrm{MA}$. As pH increases, we can see that Ni-rich film is formed.

Firstly, for the deaerated conditions $\left(\mathrm{DO}_{2}<5\right.$ ppb), Fig. 3 shows the average values of the above four parameters in the film region for Alloy $600 \mathrm{MA}$ versus solution $\mathrm{pH}$.

There is a clear correlation between the solution $\mathrm{pH}$ and the surface film depth profile. That is, chromium becomes enriched in acidic $\mathrm{pH}$, while Ni-rich tendency is observed in basic $\mathrm{pH}$.

Figure 4 shows the average values of the four parameters in the film region of Alloy 600

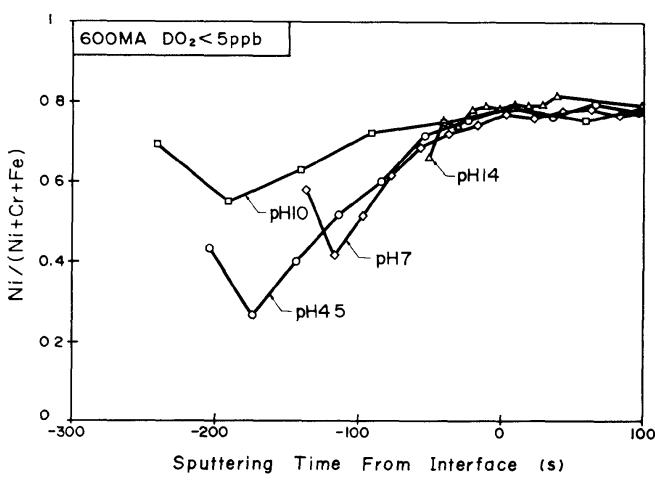

Fig. 2.1 Evaluation of Alloy $600 \mathrm{MA}$ thin film characteristics for various $\mathrm{pH}$. Test condition: $\mathrm{DO}_{2}<5 \mathrm{ppb}, 280^{\circ} \mathrm{C} \times 168$ h.

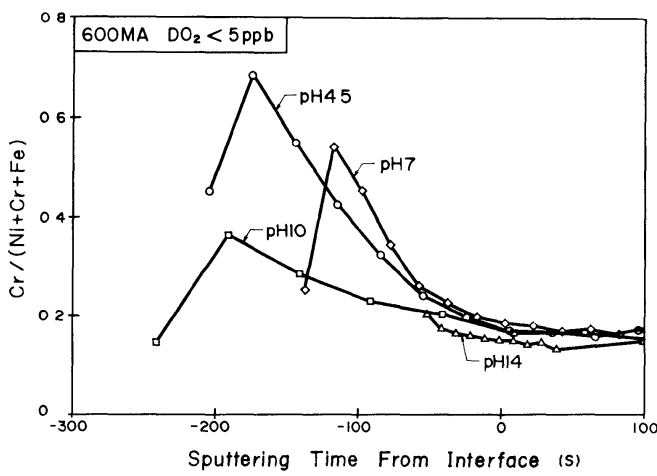

Fig. 2.2 Evaluation of Alloy $600 \mathrm{MA}$ thin film characteristics for various $\mathrm{pH}$.

Test condition: $\mathrm{DO}_{2}<5 \mathrm{ppb}, 280^{\circ} \mathrm{C} \times 168$ h.

MA for the non-deaerated conditions $\left(\mathrm{DO}_{2} \simeq 4\right.$ $\mathrm{ppm})$. As shown in these figures, the $\mathrm{pH}$ dependence of surface film depth profile is quite similar to those in the deaerated conditions for the $\mathrm{pH}$ range of $4.5-10$ of this study.

The increase in $\mathrm{DO}_{2}$ concentration causes a film that is several times thicker. The other effect of the increased $\mathrm{DO}_{2}$ is shown in the decrease in $\mathrm{Cr}$ content, resulting in $\mathrm{Ni}$ enrichment, as compared to Fig. 3.

There is no significant difference recognized for the $\mathrm{pH}$ and $\mathrm{DO}_{2}$ dependence of the depth profile of the films formed on Alloy $600 \mathrm{TT}$, as shown in Figs. 5 and 6.

\subsection{Effect of $\mathrm{pH}$ change}

(A) pH Change from Neutral to Caustic

Firstly, solution $\mathrm{pH}$ was changed from neutral to caustic in the deaerated condition to 


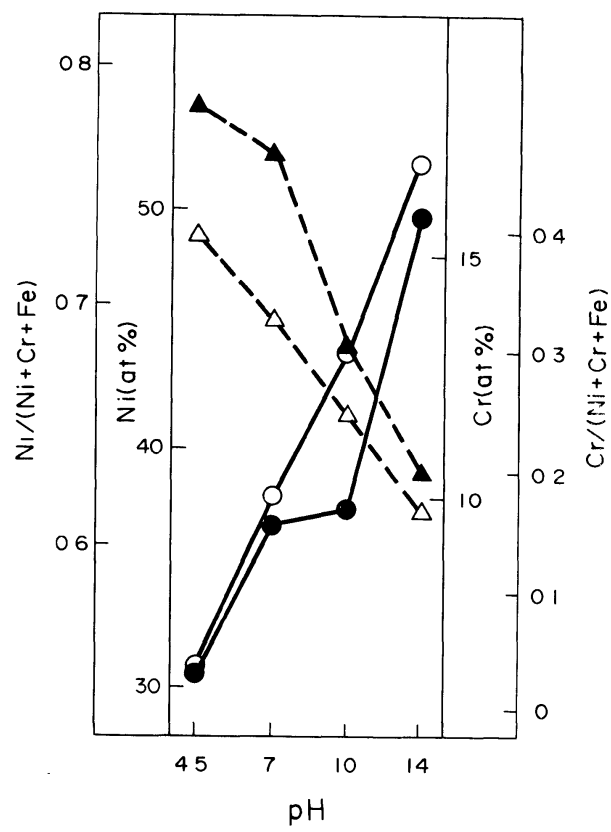

$0: \frac{\mathrm{Ni}}{\mathrm{Ni}+\mathrm{Cr}+\mathrm{Fe}} \quad \Delta: \frac{\mathrm{Cr}}{\mathrm{Ni}+\mathrm{Cr}+\mathrm{Fe}} \quad \bullet: \mathrm{Ni}(a+\%) \quad \Delta: \mathrm{Cr}(a+\%)$

Fig. 3 Average values of $\mathrm{Ni}$ at $\%, \mathrm{Cr}$ at $\%, \mathrm{Ni} /$ $(\mathrm{Ni}+\mathrm{Cr}+\mathrm{Fe})$ and $\mathrm{Cr} /(\mathrm{Ni}+\mathrm{Cr}+\mathrm{Fe})$ at $\%$ ratio in film region $(\mathrm{O} \leqq \mathrm{Ni} \leqq 60$ at $\%)$ of Alloy $600 \mathrm{MA}$.

Test condition: $\mathrm{DO}_{2}<5 \mathrm{ppb}, 280^{\circ} \mathrm{C} \times 168 \mathrm{~h}$.

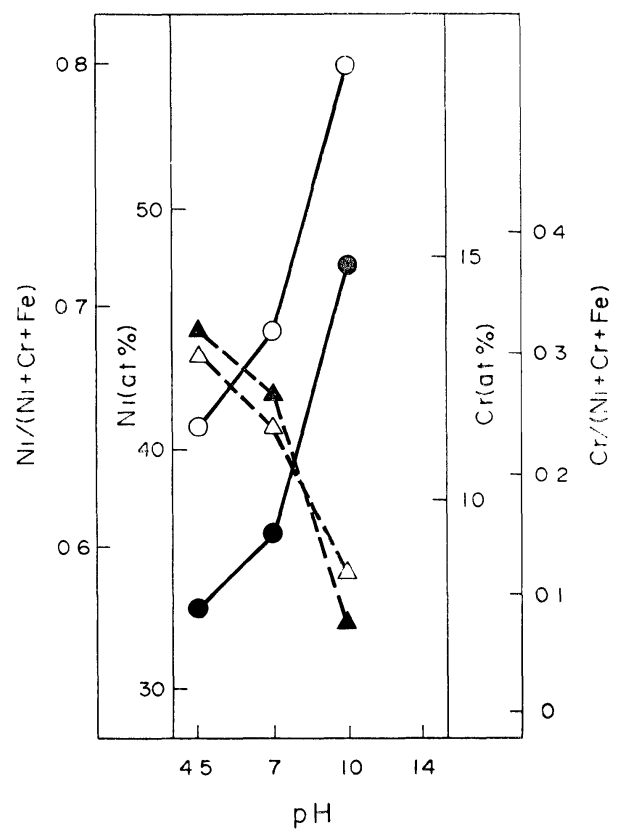

$\circ: \frac{\mathrm{N}_{1}}{\mathrm{Ni}+\mathrm{Cr}+\mathrm{Fe}} \Delta: \frac{\mathrm{Cr}}{\mathrm{N}_{1}+\mathrm{Cr}+\mathrm{Fe}} \quad \bullet: \mathrm{Ni}(a+\%) \quad \Delta: \mathrm{Cr}(0+\%)$

Fig. 4 Average values of $\mathrm{Ni}$ at $\%, \mathrm{Cr}$ at $\%, \mathrm{Ni} /$ $(\mathrm{Ni}+\mathrm{Cr}+\mathrm{Fe})$ and $\mathrm{Cr} /(\mathrm{Ni}+\mathrm{Cr}+\mathrm{Fe})$ at $\%$ ratio in film region $(0 \leqq \mathrm{Ni} \leqq 60$ at\%) of Alloy $600 \mathrm{MA}$. Test condition: $\mathrm{DO}_{2} \simeq 4$ $\mathrm{ppm}, 280^{\circ} \mathrm{C} \times 168 \mathrm{~h}$.

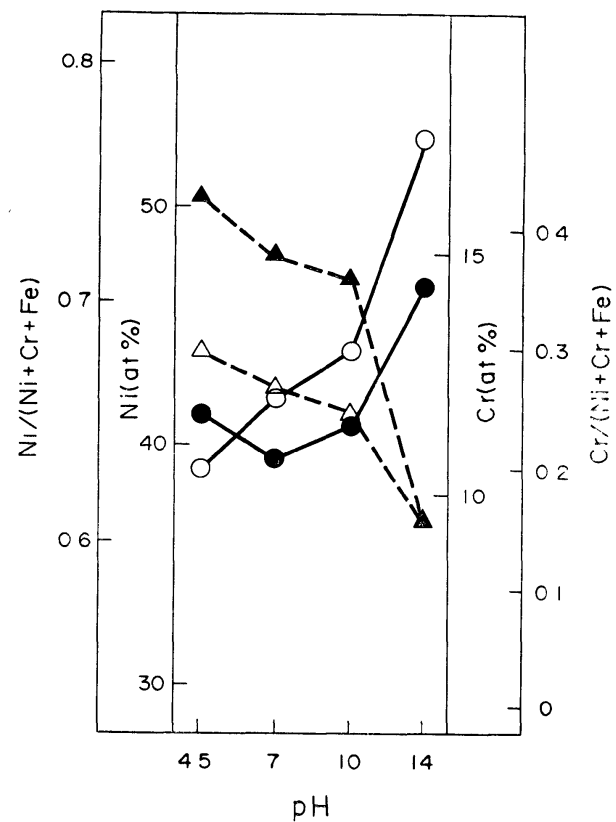

$0: \frac{\mathrm{Ni}}{\mathrm{Ni}+\mathrm{Cr}+\mathrm{Fe}} \quad \Delta: \frac{\mathrm{Cr}}{\mathrm{Ni}+\mathrm{Cr}+\mathrm{Fe}} \quad \bullet: \mathrm{Ni}(a+\%) \quad \Delta: \mathrm{Cr}(a+\%)$

Fig. 5 Average values of $\mathrm{Ni}$ at $\%, \mathrm{Cr}$ at $\%, \mathrm{Ni} /$ $(\mathrm{Ni}+\mathrm{Cr}+\mathrm{Fe})$ and $\mathrm{Cr} /(\mathrm{Ni}+\mathrm{Cr}+\mathrm{Fe})$ at $\%$ ratio in film region $(0 \leqq \mathrm{Ni} \leqq 60$ at $\%)$ of Alloy 600 TT.

Test condition: $\mathrm{DO}_{2}<5 \mathrm{ppb}, 280^{\circ} \mathrm{C} \times 168 \mathrm{~h}$.

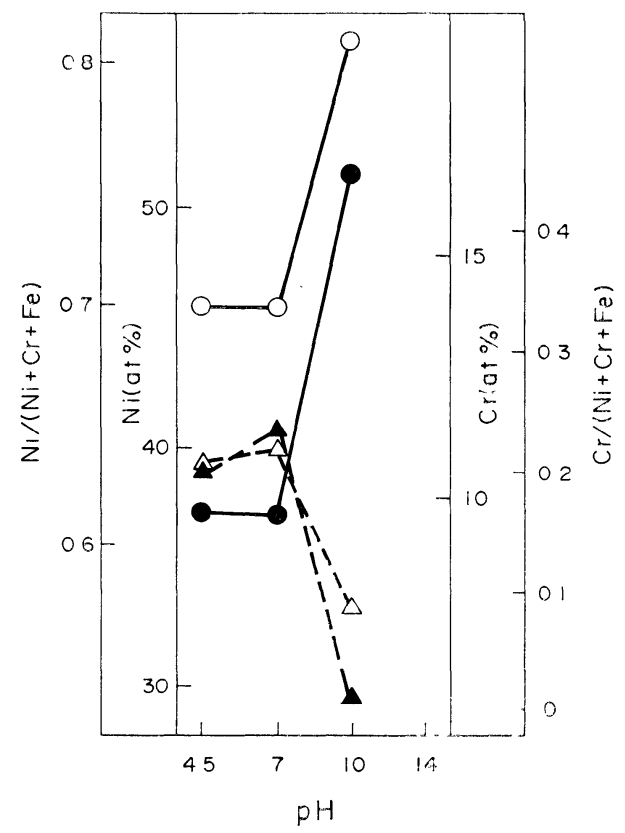

$0: \frac{\mathrm{N}_{1}}{\mathrm{Ni}+\mathrm{Cr}+\mathrm{Fe}} \quad \Delta: \frac{\mathrm{Cr}}{\mathrm{N}+\mathrm{Cr}+\mathrm{Fe}} \quad \bullet: \mathrm{N}_{1}(a+\%) \quad \Delta: \mathrm{Cr}(0+\%)$

Fig. 6 Average values of $\mathrm{Ni}$ at $\%, \mathrm{Cr}$ at $\%, \mathrm{Ni} /$ $(\mathrm{Ni}+\mathrm{Cr}+\mathrm{Fe})$ and $\mathrm{Cr} /(\mathrm{Ni}+\mathrm{Cr}+\mathrm{Fe})$ at $\%$ ratio in film region $(0 \leqq \mathrm{Ni} \leqq 60$ at $\%)$ of Alloy $600 \mathrm{TT}$.

Test condition: $\mathrm{DO}_{2} \simeq 4 \mathrm{ppm}, 280^{\circ} \mathrm{C} \times 168 \mathrm{~h}$. 


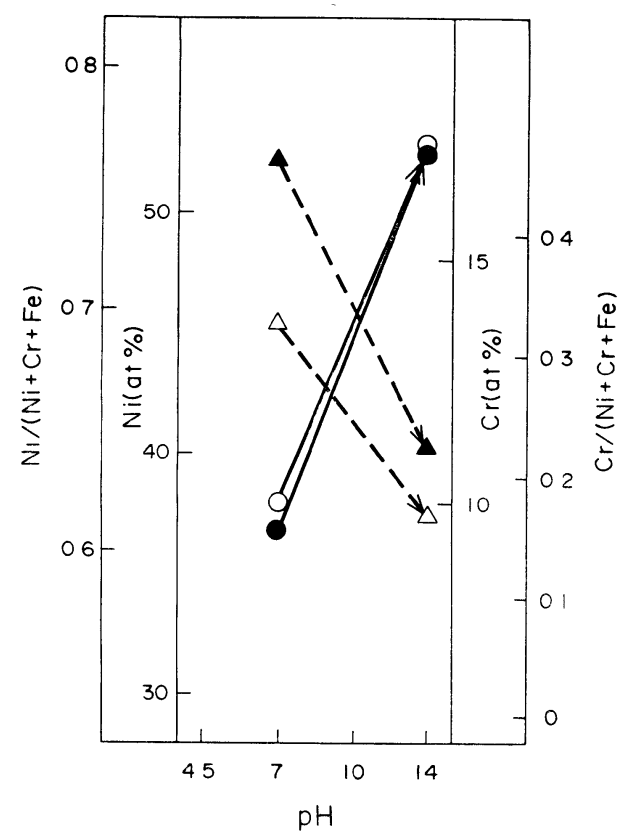

$0: \frac{\mathrm{N}_{1}}{\mathrm{Ni}+\mathrm{Cr}_{\mathrm{Fe}}} \quad \Delta: \frac{\mathrm{Cr}}{\mathrm{N}_{1}+\mathrm{Cr}+\mathrm{Fe}} \quad \bullet: \mathrm{N}_{1}(a+\%) \quad \Delta: \mathrm{Cr}(a+\%)$

Fig. 7 Average values of $\mathrm{Ni}$ at $\%, \mathrm{Cr}$ at $\%, \mathrm{Ni} /$ $(\mathrm{Ni}+\mathrm{Cr}+\mathrm{Fe})$ and $\mathrm{Cr} /(\mathrm{Ni}+\mathrm{Cr}+\mathrm{Fe})$ at $\%$ ratio in film region $(0 \leqq \mathrm{Ni} \leqq 60$ at $\%)$ of Alloy 600 MA.

Test condition: pH $7(168 \mathrm{~h}) \rightarrow \mathrm{pH} 14(168 \mathrm{~h})$, $\mathrm{DO}_{2}<5 \mathrm{ppb}, 280^{\circ} \mathrm{C}$.

simulate an accidental caustic ingress into a steam generator. The depth profiles of two specimens were measured. One specimen had been exposed in $\mathrm{pH} 7$ for one week, while the other had been exposed in $\mathrm{pH} 14$ for a second week after one week of exposure in $\mathrm{pH} 7$.

The average values of the four parameters (Ni at $\%, \mathrm{Cr}$ at $\%, \mathrm{Ni} / \mathrm{Ni}+\mathrm{Cr}+\mathrm{Fe}$ at $\%$ ratio, $\mathrm{Cr} / \mathrm{Ni}+\mathrm{Cr}+\mathrm{Fe}$ at \% ratio) in the film region $(0 \leqq \mathrm{Ni} \leqq 60$ at $\%)$ and the film thickness are compared in Figs. 7-9, respectively.

These data indicate the change of film composition and thickness due to solution $\mathrm{pH}$ changed from neutral to caustic. The decrease of $\mathrm{Cr}$ content is clearly observed in the additional one week of exposure in caustic pH. Also the film thickness decreased to nearly half of the pre-existing film formed in neutral $\mathrm{pH}$. As a result, the depth profile of the thin film after two weeks of exposure resembles to that of only one week exposure in $\mathrm{pH} 14$.

In agreement with the Pourbaix diagram, $\mathrm{Cr}$ oxide is so unstable in high caustic condition

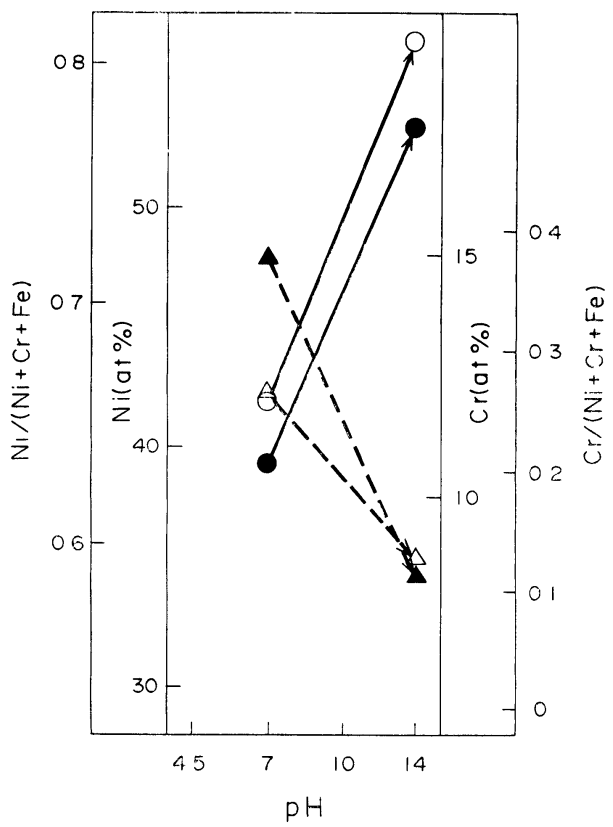

$O: \frac{\mathrm{N}_{t}}{\mathrm{Ni}+\mathrm{Cr}+\mathrm{Fe}} \quad \Delta: \frac{\mathrm{Cr}}{\mathrm{Ni}_{1}+\mathrm{Cr}+\mathrm{Fe}} \quad \bullet: \mathrm{N}_{1}(a \dagger \%) \quad \Delta: \mathrm{Cr}(a+\%)$

Fig. 8 Average vaules of $\mathrm{Ni}$ at $\%, \mathrm{Cr}$ at $\%, \mathrm{Ni} /$ $(\mathrm{Ni}+\mathrm{Cr}+\mathrm{Fe})$ and $\mathrm{Cr} /(\mathrm{Ni}+\mathrm{Cr}+\mathrm{Fe})$ at $\%$ ratio in film region $(0 \leqq \mathrm{Ni} \leqq 60$ at $\%)$ of Alloy 600 TT.

Test condition: pH $7(168 \mathrm{~h}) \rightarrow$ pH $14(168 \mathrm{~h})$, $\mathrm{DO}_{2}<5 \mathrm{ppb}, 280^{\circ} \mathrm{C}$.

that it is concluded that the $\mathrm{pH}$ change to high caustic caused the dissolution of pre-existing $\mathrm{Cr}$ oxide and made the film completely reform.

There is no significant difference in the effect of $\mathrm{pH}$ change on the films of Alloy $600 \mathrm{MA}$ and $600 \mathrm{TT}$.

(B) $\mathrm{pH}$ Change from Caustic to Neutral or Mild Acidic

The second investigation was performed to evaluate the influence on the surface film of a pH shift in the opposite direction. Three specimens were prepared. One was exposed in $\mathrm{pH}$ 14 for one week. The others were exposed in $\mathrm{pH} 4.5$ or $\mathrm{pH} \mathrm{7,} \mathrm{respectively,} \mathrm{for} \mathrm{an} \mathrm{additional}$ one week after removal from the one-week exposure to $\mathrm{pH} 14$.

The typical depth profile for Alloy $600 \mathrm{MA}$ after the Test No. III-3 are shown in Fig. 10. The average values of $\mathrm{Ni}$ at $\%, \mathrm{Cr}$ at $\%, \mathrm{Ni} / \mathrm{Ni}+$ $\mathrm{Cr}+\mathrm{Fe}$ at $\%$ ratio and $\mathrm{Cr} / \mathrm{Ni}+\mathrm{Cr}+\mathrm{Fe}$ at $\%$ ratio, as shown in Figs. 11 and 12, indicate a change in film composition and thickness, depending on the change of solution $\mathrm{pH}$. The 


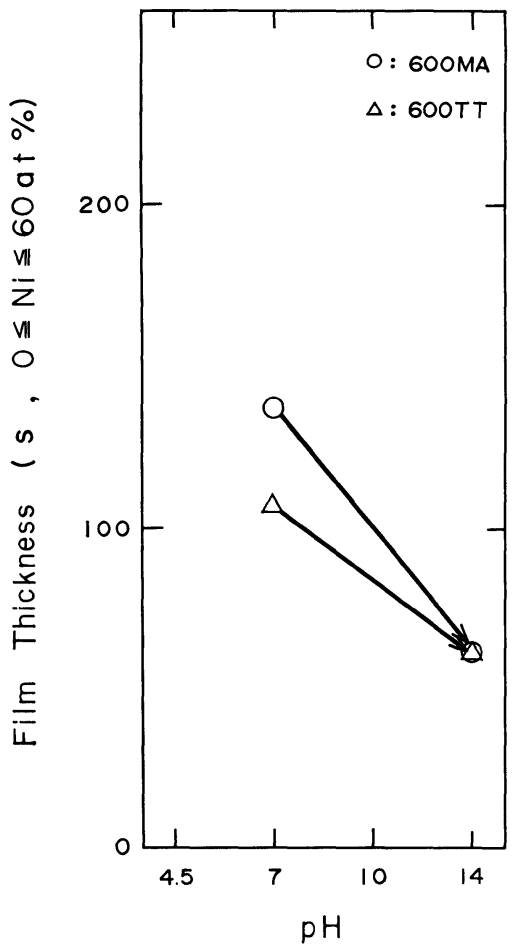

Fig. 9 The change of thin film thickness of Alloy $600 \mathrm{MA}$ and $600 \mathrm{TT}$.

Test condition: pH $7(168 \mathrm{~h}) \rightarrow \mathrm{pH} 14(168 \mathrm{~h})$, $\mathrm{DO}_{2}<5 \mathrm{ppb}, 280^{\circ} \mathrm{C}$.

decrease of Ni-content and $\mathrm{Cr}$-enrichment are observed in the additional one week exposure in neutral or mild acidic pH. The degree of this change appears larger for the case from caustic to mild acidic than for the case from caustic to neutral. In comparing with Figs. 3 and 5 , this tendency is quite consistent with that of the film formed in the fixed $\mathrm{pH}$ condition for one week.

Contrary to this general $\mathrm{pH}$ dependency, the depth profile in Fig. 10 shows a double layer structure, especially in $\mathrm{Ni}$ distribution, which is different from that of the one-week exposure in $\mathrm{pH} 4.5$ or $\mathrm{pH} 7$ shown in Fig. 1. There is a Ni plateau region on the outer film region in Fig. 10. Also the different appearance is observed in the plots of $\mathrm{Ni} / \mathrm{Ni}+\mathrm{Cr}+\mathrm{Fe}$ at $\%$ ratio and $\mathrm{Cr} / \mathrm{Ni}+\mathrm{Cr}+\mathrm{Fe}$ at $\%$ ratio. According to the Pourbaix diagram applicable for equilibrium condition, $\mathrm{Ni}$ oxide is still stable in neutral and/or mild acidic solutions. Therefore, the experimental data might mean that the $\mathrm{Ni}$ oxide which had been formed in the caustic condition is stable also in the neutral or mild

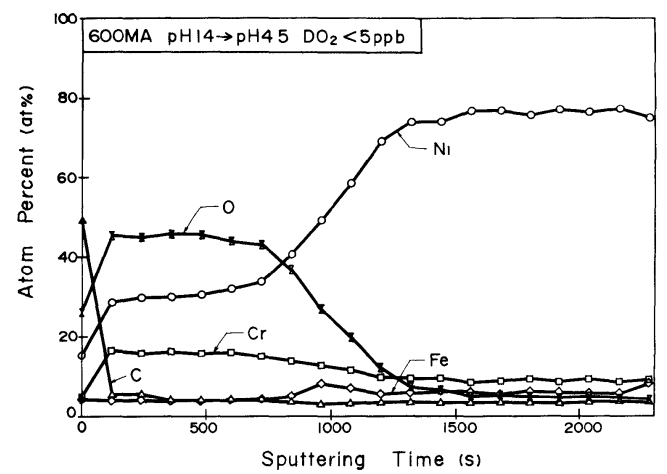

F1g. 10 Depth profile of Alloy $600 \mathrm{MA}$. Test condition: $\mathrm{pH} 14(168 \mathrm{~h}) \rightarrow \mathrm{pH} 4.5$ (168 h), $\mathrm{DO}_{2}<5 \mathrm{ppb}, 280^{\circ} \mathrm{C}$.

acidic condition and covers the outer region of thin film, while the new film formation in the subsequent new water chemistry continues actively in the entire film region. This fact of active film formation is also reflected in the large increase in film thickness, that is, about a factor of eighteen and twentyfive for the Test No. III-2 (pH $14 \rightarrow \mathrm{pH} 7)$ and III-3 (pH 14 $\rightarrow \mathrm{pH} 4.5$ ) respectively, for both Alloy $600 \mathrm{MA}$ and $600 \mathrm{TT}$.

As in other cases studied here, there is no significant difference in the effect of $\mathrm{pH}$ change on the films of Alloy $600 \mathrm{MA}$ and $600 \mathrm{TT}$. The test results are summarized in Table 4.

\section{Conclusions}

1. The depth profiles of surface film on Alloy 600 formed in high temperature aqueous solutions have been clarified quantitatively. The film shows depth profile specific to both $\mathrm{pH}$ and $\mathrm{DO}_{2}$ level in the solution. Chromium in the film gets enriched in more acidic and lower $\mathrm{DO}_{2}$ condition, while nickel becomes enriched in the opposite condition. This general tendency is consistent with the thermodynamic stability of $\mathrm{Ni}$ and $\mathrm{Cr}$ oxides based on the Pourbaix diagram applicable to the equilibrium condition.

2. The $\mathrm{pH}$ change definitely affects the film depth profile. The current study demonstrates this observation for the case of $\mathrm{pH}$ change from neutral to caustic and vice versa in the deaerated condition.

3. Any difference in the depth profile of film composition between Alloy $600 \mathrm{MA}$ and Alloy 600 TT was not significantly identified macroscopically within the scope of this study.

(Received March 15, 1991) 


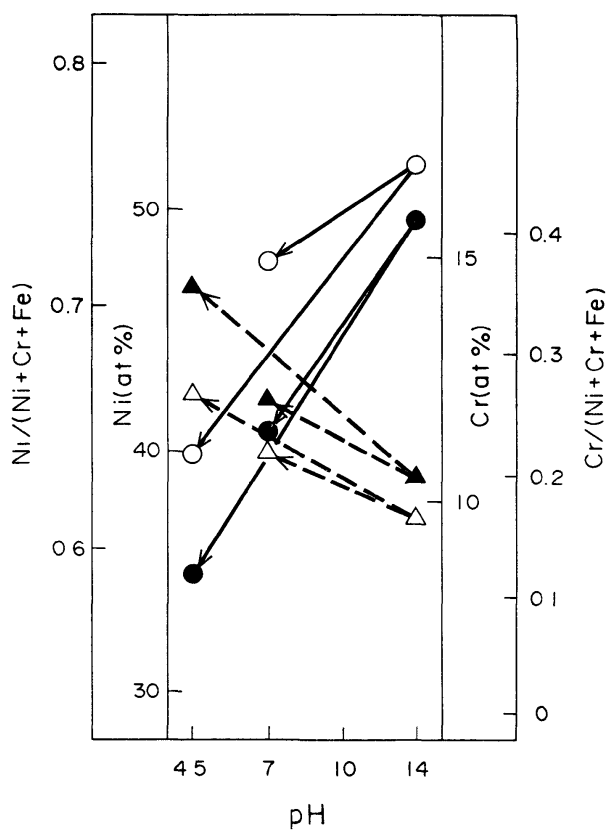

$0: \frac{\mathrm{N}_{1}}{\mathrm{Ni}+\mathrm{Cr}+\mathrm{Fe}} \quad \Delta: \frac{\mathrm{Cr}}{\mathrm{Ni}_{1}+\mathrm{Cr}_{r}+\mathrm{Fe}} \quad \bullet: \mathrm{N}(\mathrm{a}+\%) \quad \Delta: \mathrm{Cr}(0+\%)$

Fig. 11 Average values of $\mathrm{Ni}$ at $\%, \mathrm{Cr}$ at $\%, \mathrm{Ni} /$ $(\mathrm{Ni}+\mathrm{Cr}+\mathrm{Fe})$ and $\mathrm{Cr} /(\mathrm{Ni}+\mathrm{Cr}+\mathrm{Fe})$ at $\%$ ratio in film region $(0 \leqq \mathrm{Ni} \leqq 60$ at $\%)$ of Alloy 600 MA.

Test condition: $\mathrm{pH} 14(168 \mathrm{~h}) \rightarrow \mathrm{pH} 7 / \mathrm{pH}$ $4.5(168 \mathrm{~h}), \mathrm{DO}_{2}<5 \mathrm{ppb}, 280^{\circ} \mathrm{C}$.

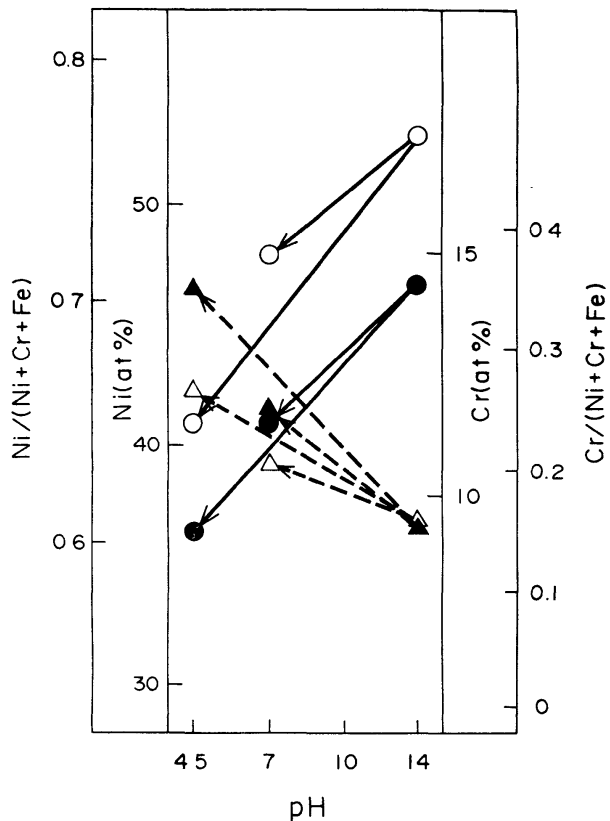

$\circ: \frac{\mathrm{Ni}}{\mathrm{Ni}+\mathrm{Cr}+\mathrm{Fe}} \Delta: \frac{\mathrm{Cr}}{\mathrm{Ni}+\mathrm{Cr}+\mathrm{Fe}} \quad \bullet: \mathrm{Ni}(a+\%) \quad \Delta: \mathrm{Cr}(a+\%)$

Fig. 12 Average values of $\mathrm{Ni}$ at $\%, \mathrm{Cr}$ at $\%, \mathrm{Ni} /$ $(\mathrm{Ni}+\mathrm{Cr}+\mathrm{Fe})$ and $\mathrm{Cr} /(\mathrm{Ni}+\mathrm{Cr}+\mathrm{Fe})$ at $\%$ ratio in film region $(0 \leqq \mathrm{Ni} \leqq 60$ at $\%)$ of Alloy 600 TT.

Test condition: $\mathrm{pH} 14(168 \mathrm{~h}) \rightarrow \mathrm{pH} 7 / \mathrm{pH}$ $4.5(168 \mathrm{~h}), \mathrm{DO}_{2}<5 \mathrm{ppb}, 280^{\circ} \mathrm{C}$.

Table 4 Summary of test results.

\begin{tabular}{|c|c|c|c|c|c|c|c|}
\hline \multirow{3}{*}{$\begin{array}{l}\text { Test } \\
\text { No. }\end{array}$} & \multicolumn{2}{|c|}{ Test Solution } & \multicolumn{5}{|c|}{ Film Characteristics *2 } \\
\hline & \multirow{2}{*}{$\mathrm{pH}^{* 1}$} & \multirow{2}{*}{$\mathrm{DO}_{2}$} & \multicolumn{2}{|c|}{ Average Content } & \multirow{2}{*}{$\begin{array}{l}\text { Average } \\
\text { Composition } \\
\text { Ratio }\end{array}$} & \multirow{2}{*}{$\begin{array}{c}\text { Heat } \\
\text { Treatment }\end{array}$} & \multirow{2}{*}{ Comments } \\
\hline & & & $\mathbf{N i}$ & $\mathrm{Cr}$ & & & \\
\hline \multirow{4}{*}{ I } & 4.5 & \multirow{4}{*}{$<5 \mathrm{ppb}$} & \multirow{4}{*}{$\bigsqcup_{\text {Enrichment }}^{\text {Depletion }}$} & \multirow{4}{*}{$\bigsqcup_{\text {Depletion }}^{\text {Enrichment }}$} & \multirow{4}{*}{$\coprod_{\text {Ni-rich }}^{\text {Cr-rich }}$} & \multirow{10}{*}{$\begin{array}{l}\text { No } \\
\text { Significant } \\
\text { Difference }\end{array}$} & \multirow{7}{*}{$\begin{array}{l}\text { - } \mathrm{pH} \text { Dependent } \\
\text { - More Ni-rich in High } \mathrm{DO}_{2} \text { than Low } \\
\mathrm{DO}_{2}\end{array}$} \\
\hline & 7 & & & & & & \\
\hline & 10 & & & & & & \\
\hline & 14 & & & & & & \\
\hline \multirow{3}{*}{ II } & 4.5 & \multirow{3}{*}{$\approx 4 \mathrm{ppm}$} & \multirow{3}{*}{$\bigsqcup_{\text {Enrichment }}^{\text {Depletion }}$} & \multirow{3}{*}{$\underbrace{\text { Enrichment }}_{\text {Depletion }}$} & \multirow{3}{*}{$\downarrow_{\text {Ni-rich }}^{\text {Cr-rich }}$} & & \\
\hline & 7 & & & & & & \\
\hline & 10 & & & & & & \\
\hline \multirow[t]{3}{*}{ III } & $7 \rightarrow 14$ & \multirow[t]{3}{*}{$<5 \mathrm{ppb}$} & Enrichment & Depletion & Ni-rich & & $\begin{array}{l}\text { - Dissolution of } \mathrm{Cr} \text { oxide in caustic } \\
\text { - Decrease of film thickness }\end{array}$ \\
\hline & $14 \rightarrow 7$ & & \multirow[b]{2}{*}{ Depletion } & \multirow[b]{2}{*}{ Enrichment } & \multirow[b]{2}{*}{ Cr-rich } & & \multirow{2}{*}{$\begin{array}{l}\text { - Pre-existing Ni-oxide still stable in } \\
\text { neutral or mild acidic } \\
\text { - Increase of film thickness }\end{array}$} \\
\hline & $14 \rightarrow 4.5$ & & & & & & \\
\hline
\end{tabular}

*1 $\mathrm{pH}$ at room temperature.

*2 Film region: $0 \leqq \mathrm{Ni} \leqq 60$ at $\%$. 


\section{References}

1) A. Kishida, H. Takamatsu, H. Kitamura, S. Isobe, K. Onimura, K. Arioka, T. Hattori, T. Arai \& M. Sato: Proc. Third International Symposium on Environmental Degradation of Materials in Nuclear Power SystemsWater Reactors, p. 465, Traverse City, USA (1987).

2) R.S. Pathania, J. P. N. Paine \& C. E. Shoemaker: Proc. Third International Symposium on Environmental Degradation of Materials in Nuclear Power Systems-Water Reactors, p. 511, Traverse City, USA (1987).

3) O. Cayla, P. Combrade \& G. Slama: Proc. Second International Symposium on Environmental Degradation of Materials in Nuclear Power Systems-Water Reactors, p. 464, Monterey, USA (1985).

4) P. Combrade, O. Cayla, A. Gelpi \& G. Slama: Proc. Third International Symposium on Environmental Degradation of Materials in Nuclear Power Systems-Water Reactors, p. 525, Traverse City, USA (1987).

5) B. P. Miglin, L. W. Sarver, J. V. Monter \& G. J. Theus: Proc. Third International Sympo- sium on Environmental Degradation of Materials in Nuclear Power Systems-Water Reactors, p. 535, Traverse City, USA (1987).

6) J. B. Lumsden: EPRI Report NP-5712 (1988).

7) T. Sakai, S. Okabayashi, K. Aoki, K. Matsumoto \& Y. Kishi: NACE Corrosion 90, paper No. 520, Las Vegas, USA (1990).

8) T. Sakai, K. Aoki, T. Shigemitsu \& Y. Kishi: Proc. SFCA International Symposium Fontevraud II Vol. 2, p. 1, Fontevraud, France (1990).

9) Edited by M. Pourbaix: "Atlas of Electrochemical Equilibria in Aqueous Solutions", Pergamon Press (1966).

10) C. M. Chen, K. Aral \& G. J. Theus: EPRI Report NP-3117, Vol. 2 (1983).

11) N. S. McIntyre, D. G. Zetaruk \& D. Owen: J. Electrochem. Soc. 126, 750 (1979).

12) H. Hirano \& H. Takaku: CRIEPI Report No. 285056 (1985).

13) J. B. Lumsden \& P. J. Stocker: Proc. Fourth International Symposium on Environmental Degradation of Materials in Nuclear Power Systems-Water Reactors, p. 6-38, Jekyll Island, USA (1989). 